\title{
Recognizing the Similar and Thus Accepting the Other: The European and Japanese Traditions of Building With Wood
}

\author{
Reconocer lo semejante para aceptar lo diferente: Las \\ tradiciones europea y japonesa de construcción en \\ madera
}

Reconhecendo o semelhante, aceitando assim o outro:

As tradições europeias e japonesas da construção em madeira

\author{
Keywords | Palabras clave | Palavras chave \\ Identity, Perception, Pragmatic building solutions, Building cultures, Typology \\ Identidad, Percepción, Soluciones constructivas pragmáticas, Culturas constructivas, Tipología \\ Identidade, Percepção, Soluções de Construção Pragmáticas, Culturas de Construção, Tipologia
}

\begin{abstract}
Resumen | Resumo
This article shows that building issues have not been tackled fundamentally differently in Europe and Japan despite large cultural differences. Different cultural expressions must not necessarily be equated with different thinking. The paper contrasts two apparently contradictory views. Numerous analyses of Japanese "otherness" in "Western" as well as local perception dominate the literature. But the results of extensive architectural field surveys seem to indicate the contrary. These results show similar and equal backgrounds and conditions resulting in similar and equal building types and techniques. They show that our ways of addressing a task are prompted by pragmatism. Broadly identical solutions were developed worldwide long before globalization. Yet this realization does not allow us to conclude that equal appearances can be taken to be equal in content.
\end{abstract}

Este artículo muestra que la forma de afrontar los problemas de construcción no era esencialmente distinta en Europa y Japón, a pesar de las grandes diferencias culturales. Expresiones culturales diversas no implican inevitablemente formas diferentes de pensar. Este artículo compara dos hechos aparentemente contradictorios. Una amplia gama de análisis de la “otredad” japonesa en la percepción “occidental”, así como en la autóctona, domina el discurso científico. Los resultados de exhaustivas investigaciones arquitectónicas sobre el terreno parecen demostrar lo contrario. Estos resultados ponen de relieve que antecedentes y condiciones similares e iguales dan lugar a tipologías de edificios y técnicas constructivas similares e iguales. Además, demuestran que los métodos para afrontar una tarea están predominantemente marcados por el pragmatismo. Por todo el mundo se desarrollaron soluciones idénticas mucho antes de la globalización. Sin embargo, este descubrimiento no debe llevarnos a la conclusión de que un mismo aspecto puede evaluarse igualmente en cuanto a su contenido. 
Este artigo mostra que o confronto com os problemas presentes na construção não foi abordado de forma fundamentalmente diferente na Europa e no Japão, apesar das grandes diferenças culturais. As diferentes expressões culturais não devem ser inevitavelmente equiparadas com um pensamento diferente. $\mathrm{O}$ artigo coloca em oposição dois factos aparentemente contraditórios. Uma vasta gama de análises da "alteridade” Japonesa na percepção "Ocidental" bem como indígena domina o discurso científico. Os resultados de extensos estudos arquitectónicos de campo parecem provar o contrário. Estes resultados realçam que alguns antecedentes e condições que são semelhantes e iguais, dão lugar a tipologias de construção e técnicas de construção que também são semelhantes e iguais. Revelam que os métodos utilizados pelas pessoas para enfrentar uma tarefa são fortemente guiados pelo pragmatismo. Soluções globalmente idênticas foram desenvolvidas por toda a parte muito antes da globalização. No entanto, esta constatação não nos permite concluir que aparências iguais podem ser avaliadas igualmente em termos de conteúdo.

\section{Introduction}

This article is based on a paper presented on the 150th anniversary of the 1869 Friendship Treaty between Austria and Japan at a symposium held in Vienna in 2019. Its subject matter is still applicable and unfortunately topical. Recklessly pursued egoism and self-interest have driven humanity into a dead-end. On realizing this, many seek support and guidance from leaders perceived as charismatic, and despite bad historical experiences they blithely sign up to strategies involving bogeymen and conspiracy theories. Politics needs strong voices proclaiming that humans basically think equally, behave equally, and feel equally all over the world.

"Friendship" can be a euphemistic term. The aforesaid Friendship Treaty was more about economic and political interests such as had been asserted in China not long before than an amicable accord. Starting with the opium wars, Western colonial powers submitted China to their benefit over the 19th century. When they sought to repeat the strategy in Japan, the Meiji Restoration government did all it could to escape this fate. They were convinced that their only chance was to study and understand Western methods and interests, fearing that Japan's experience would be like China's. The resulting Iwakura Mission is legendary, though unknown to a wider public (Nish 1998; Pantzer 2002). What is well known are the several world exhibitions at which Japan presented itself as matching its European and North American hosts, allowing Westerners to become more familiar with the Japanese nation. ${ }^{1}$ Japan's selfpresentations are striking indications of its rapidly changing self-perception and self-awareness. The consequences are well known. Japan generated surprise and fascination. Its culturally distinct "otherness" was perceived and cultivated at home as well as sought from abroad (Edlinger 2008; Schiermeier 2014). ${ }^{2}$ A perceived Japanese identity came into being.

"Self-perception" and "identity" are key terms in our approach here. A few architectural references that made Japanese "otherness" a subject of discussion as of the opening of the country in 1868 are cited as examples. Our selection deliberately does not give a coherent picture. Thus the various views will not be classified or assessed. This broad picture is contrasted with personal observation. A variety of architectural details seem to prove that the same building tasks generated the same results in both Europe and Japan. Brief analyses of juxtaposed examples show also that the similarity does not stop with appearance. We conclude cautiously that the theory of otherness is at odds with similar thinking as expressed in building practice.

\section{The "other"}

Many studies and much literature deal with the so-called "other" (e.g. Yoshiaki 1995; Löffler 2015b). ${ }^{3}$ Statements such as: "Only an insular people - an isolated people - can limit itself by building with one single structural material, that is to say wood, so consistently for 2000 years" (Nitschke 2002: 15) cement stereotypes about difference. Authors emphasizing the paradoxical culture and complexity of Japan's society find "a high degree of adaptability" in its 
citizens (Bognar 1988b: 148). The advice on how to deal with this and the conclusions drawn are diverse: "Thinkers working in the contemporary styles of Western philosophy are often ill-trained in and therefore neglectful of Eastern forms of thought" (Ibid.: 162).

Heinrich Engel criticizes "Western publications on Japanese architecture [looking for] affirmation of current theories [instead of showing] serious attempts to uncover the real backgrounds" (Engel 1964: 24). Roland Barthes supports him by asserting: "This city [Tokyo] can be known only by an activity of an ethnographic kind: you must orient yourself in it not by book, by address, but by walking, by sight, by habit, by experience; here every discovery is intense and fragile, it can be repeated or recovered only by memory of the trace it has left in you" (Barthes 1983: 36).

Bruno Taut's writings were influential along the same lines. As Astrid Edlinger says about Taut: "He finds in Japan what he is looking for, as he is only looking at what matches his vision” (Edlinger 2008: 66). Manfred Speidel agrees: “Taut made himself the advocate for that, what he regarded as 'proper' Japanese, and outlawed everything not belonging to it" (Speidel 2009: 171). Taut had drawn attention to historic architectures barely noticed by locals at the time of his stay in Japan. Calling the Katsura villa a "Japanese architectural wonder of the world" (Speidel 2003: 92), he managed to impress the locals with his comments and accounts of their architecture's exceptionality.

Another quotation from Taut himself shows the problem of apodictic judgments by those who have managed to win confidence by their sensitive appreciation of unfamiliar surroundings: "It is simplicity and freshness [...] that is typical of Japan, not the Japan spoilt by undigested influences and broken and degenerated by imitation" (Taut 1937: 84). Those who might have felt most supported politically by this were probably less happy to accept a foreigner's view as supportive. Ironically, Taut's statement could have been written in one of the aggressive nationalists' political pamphlets. But Taut's statement is at the least questionable - a novice's view of a foreign country.

The actively driven opening of Japan was not to everybody's taste. "History tells us that phases of rapid [...] changes have always been experienced as destabilizing, uncomfortable and irritating" (Herrle 2008: 11). Many undereducated people and those unwilling to make the efforts required in times of change tend to fall victim to simplifying nationalistic solutions. They are open to the notion that others have caused their disadvantaged situation. Beate Löffler got to the heart of this on describing different worlds of perception: Japan "took from the "imagined empire' of the West whatever was needed" (Löffler 2015a: $100)$ to ward off the dreaded colonization. It is no surprise that the Japanese felt disparaged when the Japan of the late 19 th century was seen by the West as "mostly a source of inspiration, not one of applicable knowledge" (Ibid.).
Much the same applied to those invited by the Japanese government to teach and to build: "For the architects and civil engineers [Japan] was a place to earn money and to get large, prestigious public projects built to further career opportunities" (Ibid.).

Having spoken of "the other", we cannot ignore "Japan-ness" and "Japanese-ness" (Ciorra et al. 2016: 67-68), portraying the distinguished other. Peter Herrle writes about French influence in North Africa having created the "Arabesque" in order to express "the local" (Herrle 2008), showing that this creation of an awareness of an "own" - in this case architecture is far from an exclusive phenomenon.

The Japanese themselves coined the term Wayo. During the Kamakura period new building styles were introduced into Japan from China. By the late 12th century the architectural techniques and building methods imported from Tang China had become so natural (having been altered and adapted to Japanese taste) that Japanese people regarded traditional representative architecture of the Wayo style as Japanese. Botond Bognar interestingly suggests that this can happen in an unintended way: "Consecutive rebuildings after numerous fires provided the opportunities for [...] changes, often referred to as a process of 'Japanisation'” (Bognar 1988a: 17).

On the other hand, Japan underwent wholly local architectural developments. Shinto shrines are examples of representative architecture, and minka, commoners' houses, are vernacular buildings. To return to the doubtful statements quoted above, these were classified by Bruno Taut as "essentially un-Japanese" (Taut 1936: 14).

There are still people convinced of the notion that Japan's culture relies on copying and improving. This may be supported with numerous examples of historic architecture brought from China to Japan, though again we may speak of a "source of inspiration".

Inspiration also went the other way. A good example is Vincent van Gogh's copy of Hiroshige's Sudden Shower over Shin-Ōhashi bridge (Fig. 1). Van Gogh copied the composition and his personal ingredients are a kanji frame and the Japanese characters displaced out of the picture. Looking at the images side by side and knowing of the summer downpours in Japan and of Van Gogh's electrifying depiction of light, we can recognize innovation in Van Gogh's copy very much as innovation was described by the Roman scholar Macrobius. ${ }^{4}$

Similarly, in an exhibition at the Vienna Museum of Applied Arts dedicated to Koloman Moser, the Austrian painter, graphic artist and co-founder of the Viennese Secession, two of the works on show were an original katagami, a dyeing stencil and an upholstery fabric entitled Waves at Play (Fig. 2 ), produced by the Backhausen company. The similarities are striking. Actually we seem to see a copy, and there is no 
need to say which picture was modeled on the other. On looking closely we realize that there are also differences. Moser changed the distribution of the frolicking fish in the turbulent water. On careful inspection we detect several more alterations in the copy, or rather simplifications. My impression is that the Backhausen fabric calms the more vivid and vigorous original, perhaps through its coloring. The Backhausen fabric uses four colors whereas the paperdyeing stencil could have served for a two-tone textile. Moser probably suited his design to the different expressive possibilities inherent in the different materials (though this is pure layman's speculation).

As mentioned, Japanese people also realized that they were perceived as "other" in Western eyes, and took advantage of this. As an example, it is amusing to read Arata Isozaki's account of how former ordinary craftsmen eventually became artists and their products turned into art objects (Isozaki 2011: 4).

So to what extent is Japanese art and architecture, as a cultural expression of a people, a theoretical construct of otherness?

\section{Visual similarity}

My research subject is historical wood architecture, contrasting developments in East Asia and Europe. Usually I describe the variously obvious differences. In this paper I turn the spotlight on closeness and relationships expressed in common basic ideas, equal realizations, and common intentions, i.e. similarities.

My first example is Todai-ji shōsō-in (Fig. 3). This is a very old architectural type which has symbolic status in

1a: Sudden Shower over Shin-Ōhashi bridge and Atake, Ando Hiroshige, Cleveland Museum of Art (Wikipedia, consulted on 17/02/2021)

1b: Bridge in the rain after Hiroshige, Vincent van Gogh, Google Art Project (Wikipedia, consulted on 17/02/2021)
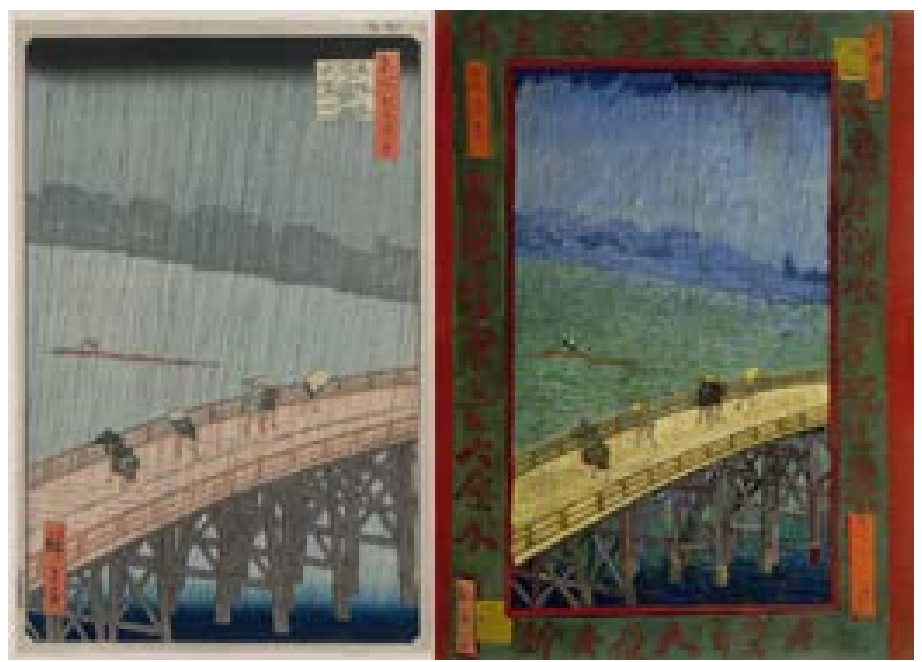

Japanese architectural history and is widely seen as typically Japanese. It reminds us of other similar storehouses built as log buildings, all elevated from the ground. We can assume that this was to protect the stored goods from rainwater and rising damp and to ventilate under the floor. All other storehouses of this type are much smaller, usually on a square plan. Although covered by just one hip roof, the three-part division of the main body leads us to ask why the central part was filled in with planks and not executed as a log structure. We do not know why, but we were told that this central part is a later addition. So what can we assume about what the building looked like before its alteration?

Before speculating, we may take a look at this Hōryū-ji kofuzo (Fig. 4). The structure is significantly different. The plastered walls in a timber-frame structure clearly indicate that this building should be seen as an import from China. This applies to the way of building, though I could not say about the building type. The Hōryzu-ji kofuzo ground plan (Fig. 5) shows what we could only assume from the previous image, as access restrictions preclude a comparable view of Todai-ji shōsō-in. In this plan we see a clear separation of two compartments by a distance as wide as the length of the enclosed spaces. The ground plan explains the installation of doors in a lengthwise axis beneath the overarching roof. This format allows a use of the store taking into account the stored items' vulnerability to the elements. Full use is normally made of the inner space of storehouses, so the handling of goods inside can be restricted and it is useful for the layout to include a large outer covered area for shelter. Whether for cereals or any other valuable items, as in the case of Todai-ji shōsō-in, goods need to be protected when taken out of the store and put into it.

If we now return to the Todai-ji shosso-in photo, what Japanese scholars have found becomes evident. The central

Figure 2a. Katagami (Museum of Applied Arts in Vienna)

Figure 2b. Design for a carpet for the company Backhausen, Koloman Moser (Museum of Applied Arts in Vienna).

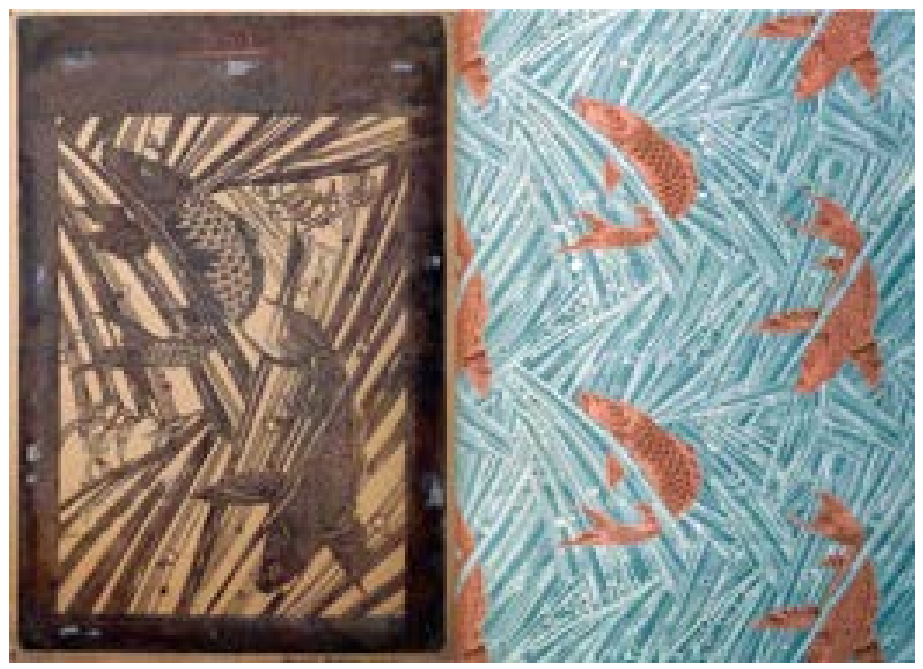




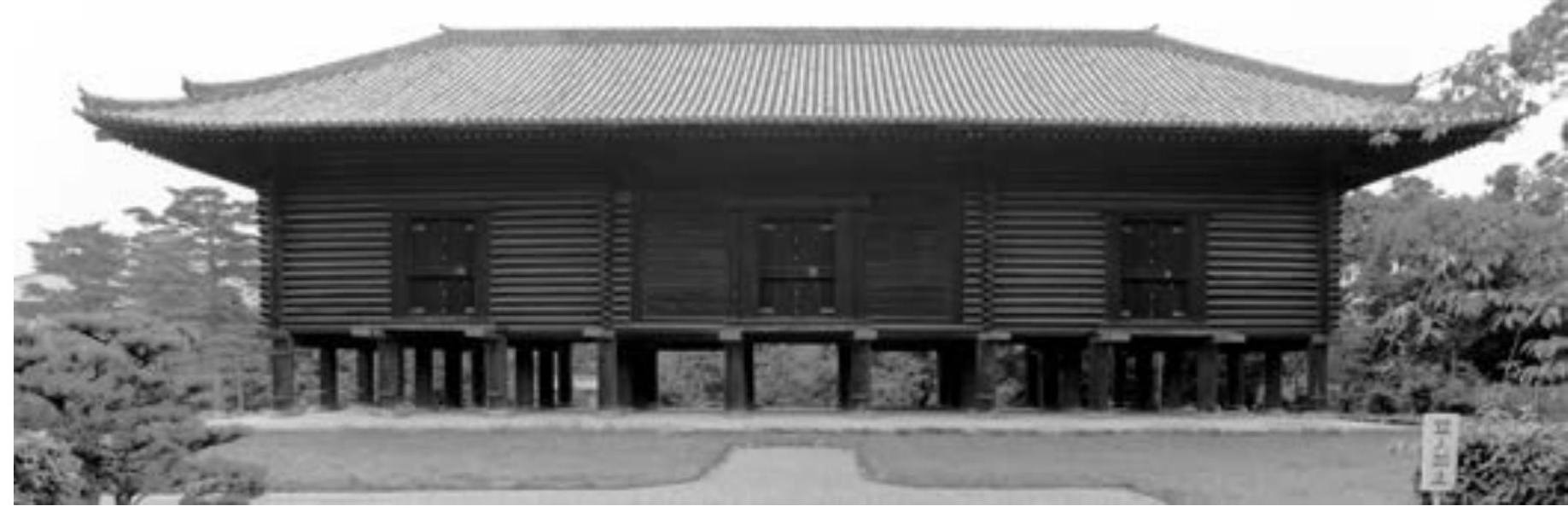

Figure 3. Todai-ji shōsō-in in Nara

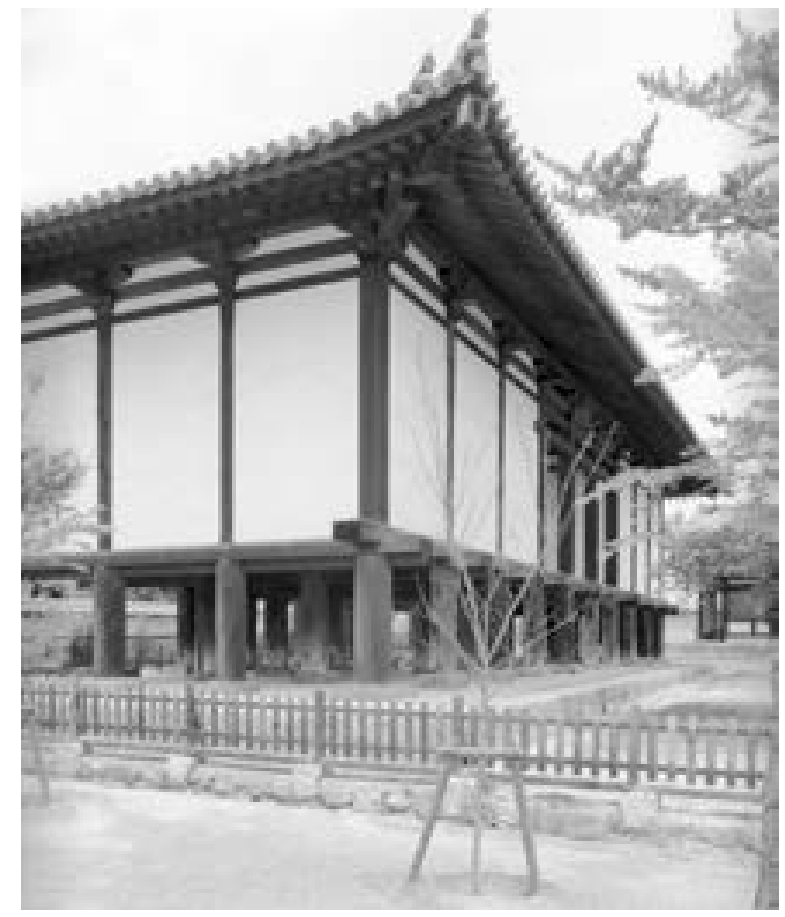

Figure 4. Hōryū-ji kofuzo in Ikaruga part was added later and was responsible for the doors being cut into the facade, altering the original positioning. The original door openings must be assumed to have been in the same positions as those seen in the Hōryū-ji kofuzo.

We may now look at the aforementioned similarities between Japanese and European architectural examples.

Let us take the example of a storehouse from Finland (Fig.6). We immediately see similarities, primarily in the three-part composition. We also see that this storehouse is not raised off the ground - for in Finland there is plenty of snow but little torrential rain, and in particular much drier air than in Japan. Again, storage space is valuable. Stores were always built with more care than other outhouses, and if they could have two stories, they did. But the typological similarity is beyond question. It is intriguing to find a nearidentical storehouse structure executed in both Europe and Japan.

Dendrochronology has turned history upside down. Todaiji shōso-in is a striking example. According to the website

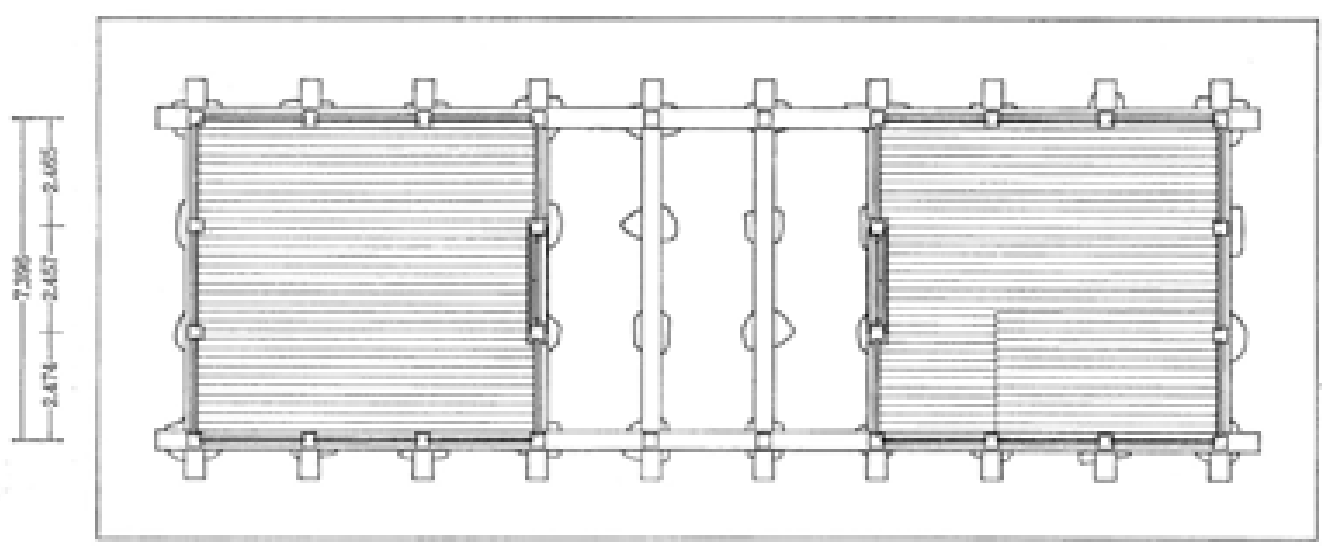

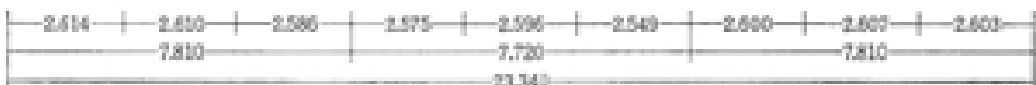

Figure 5. Hōryū-ji kofuzo ground plan (Ando 1991: 79). 
of Kunaicho, the Imperial Household Agency, research by Mitsutani Takumi in 2003 and 2006 indicates that the central part was erected together with the northern and southern azekura stores in the mid-8th century (Mitsutani 2003, 2006, 2016). But this does not prevent there being an affinity, especially if we consider the term narabi kura used for the storehouse type common in the Nara period and referring to the shōso-in type without a closed central part.

As a further example, let me present another building at the Todai temple complex: the shōrō or belfry (Fig. 7).

Like the shosso-in of Todai, the belfry survived the fire of $1567,{ }^{5}$ thus retaining elements of the daibutsu style. This building is designated as a national treasure for its age, its structure, and perhaps also its bell. And though its structural base may well not be the reason for this distinction, let us focus on this. ${ }^{6}$

Figure 6. Storehouse in the open air museum in Seurasaari in Finland

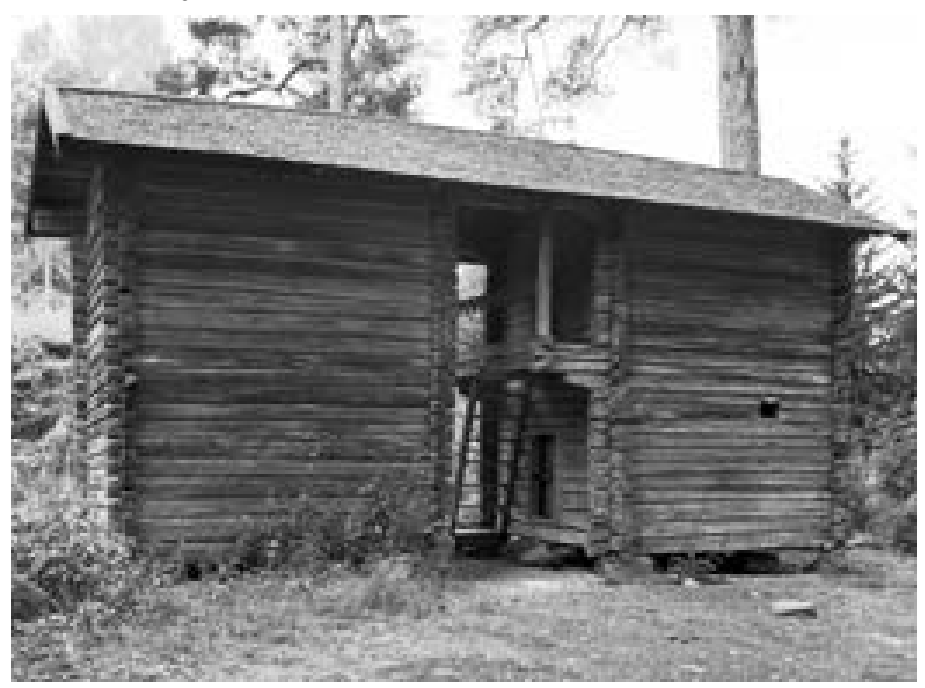

Figure 7. Todai-ji shōrō in Nara

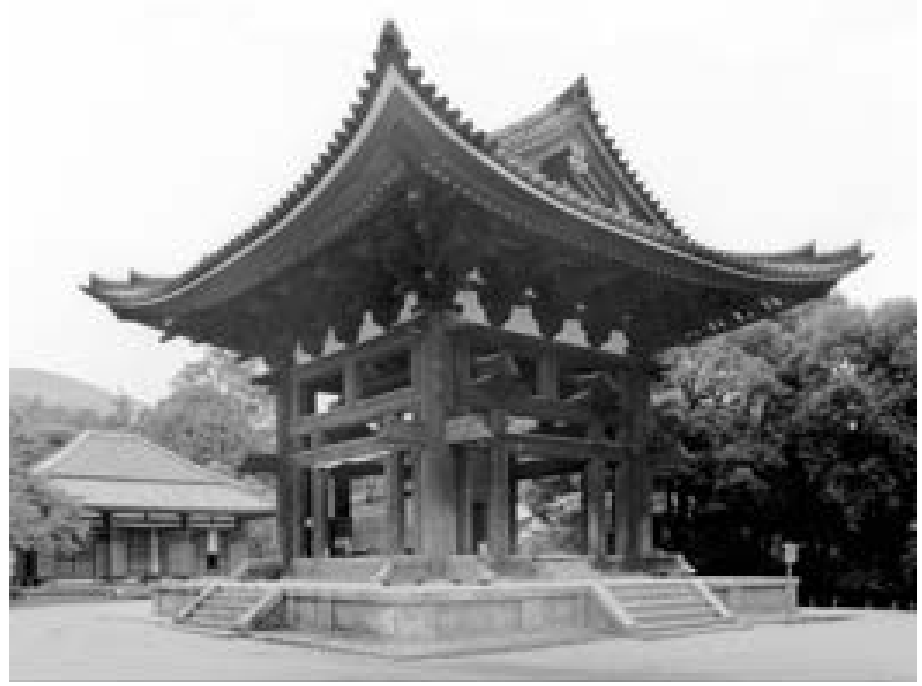

Todai-ji shōrō is not a one-off building type, so I take the example of Chion-in daishōrō to zoom in on the point of interest (Fig. 8). The Chion temple belfry shows significant structural differences as compared to that of the Todai temple. It was built in 1678 , i.e. much later. Yet the jointing of crossing sill beams and corner posts is just the same as that of the earlier example.

Again I offer a matching European counterpart in order to show that carpenters created similar solutions worldwide as long as these were suitable and no external factors ${ }^{7}$ prevented such developments: the stave church of Hopperstad in Norway (Fig. 9). We can assume that there was no Japanese-Norwegian cultural exchange prior to this building task. According to dendrochronological tests with various results, scholars assume this church to have been erected between the 11th and 12th centuries. Now let us focus on a corner post of the core section. This area was surrounded by an ambulatory recognizable by the pent

Figure 8. Bell tower of Chion-in in Kyoto

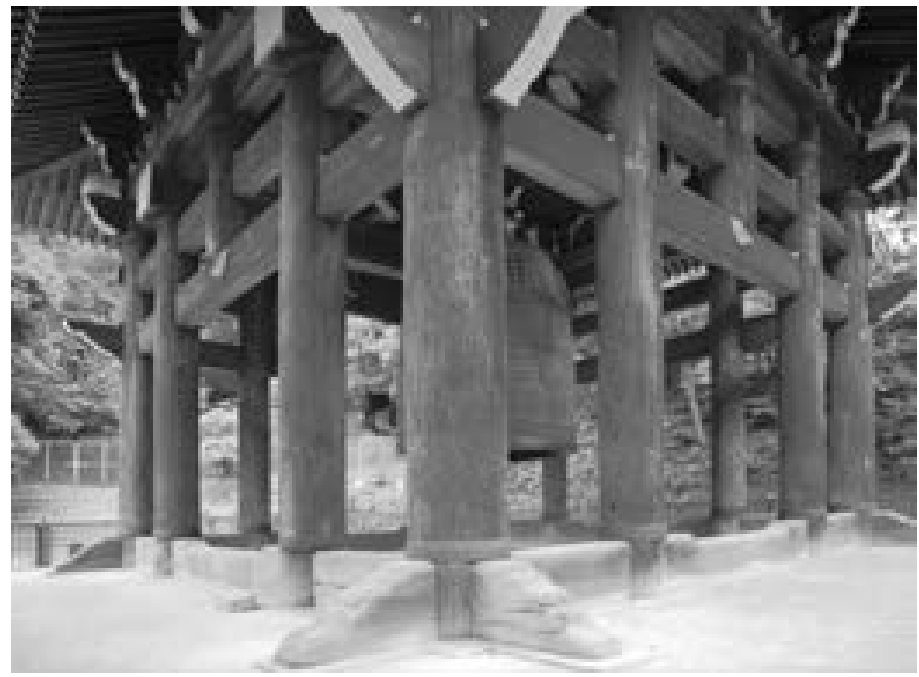

Figure 9a. Stave church in Hopperstad, Norway

Figure 9b. Corner pillar of the church in Hopperstad

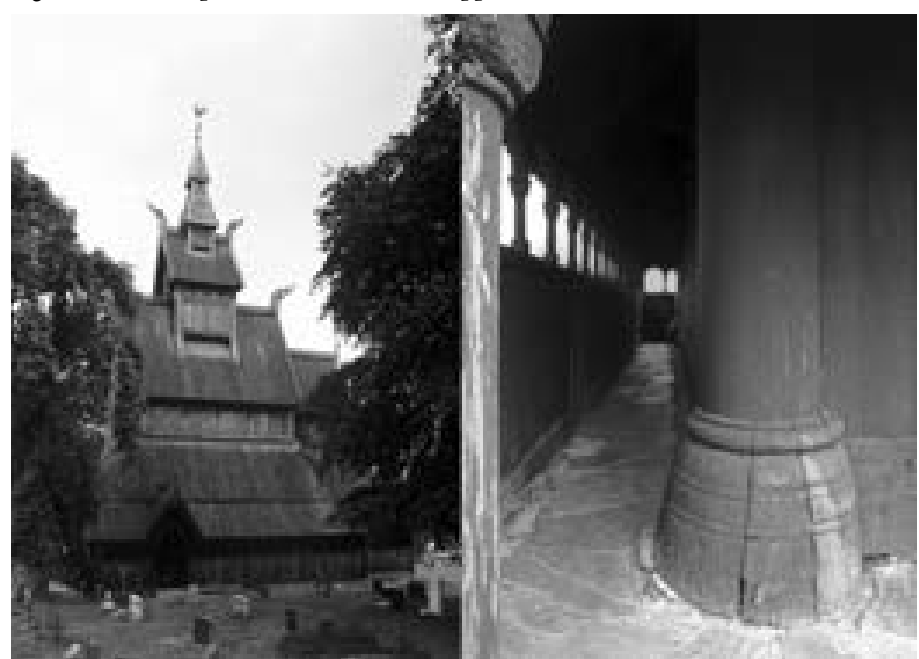


roofs around the core. Four heavy sill beams rest on a stone foundation. The sills are interconnected by half-notches near their ends, creating a rigid frame. The corner post is cross-cut at its bottom end (like that in Fig. 10). The forked ends clasp the jointing point of the crossing sills and the recessed notches fix the beams in position. The ingenuity of this joint lies in its protective nature. As the interconnection of the horizontal beams is protected against intrusion of water, especially at their vulnerable ends, the joint material is perfectly shielded. This joint serves two functions: the post protects the interconnection of three structural members and holds them secure. This jointing method is applicable in any other comparable situation and is found not just in representative buildings but also in dwellings (like that in Fig. 10).

Our next examples are raised storehouses in a different context: Amami Oshima, an island between Kyushu and Okinawa (Fig. 11). Rice storehouses had to resist typhoons

Figure 10a. Farmhouse in the open air museum in Bygdoy, Norway Figure 10b. Drawing of the corner joint of a Norwegian stave church
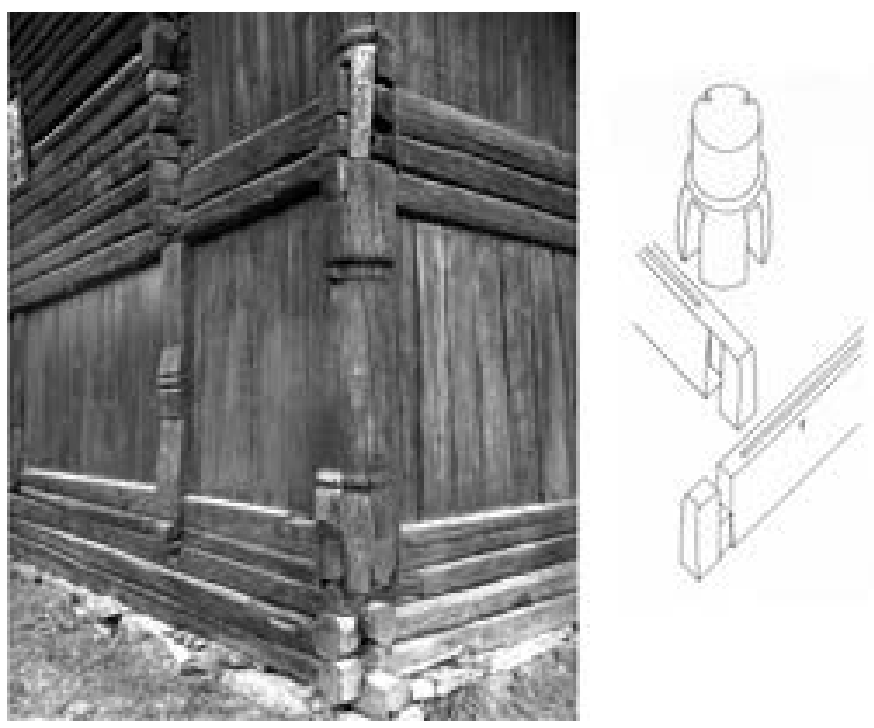

Figure 11. Rice storehouses in Yamatohama

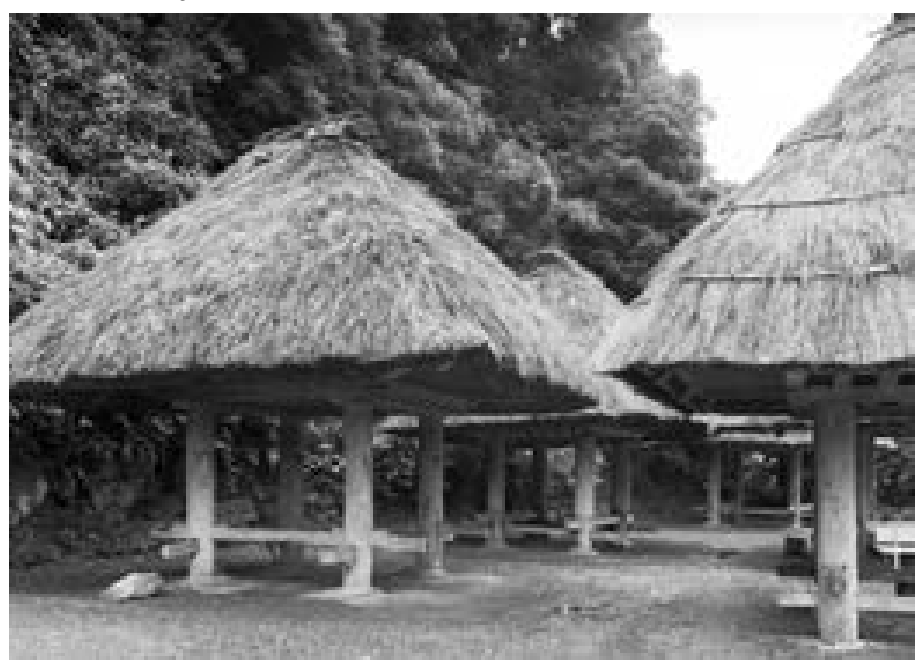

with wind speeds of $200 \mathrm{~km} / \mathrm{h}$ and the building design and elevation had to be suited to this. And as in Japan, storehouses in Europe were built on pillars of variable height (Fig. 12). An elevated storehouse in Japan, like in Europe, must address one main issue: how to keep the stored items dry and ventilated. The pillars were designed to protect the stored goods and also the structure itself, and if people wanted to use the sheltered space below, they had to raise the building high enough to leave enough room. Structurally it is quite demanding to raise the center of gravity upward. The Japanese temple storehouses shown above held exquisite treasures, but common stores are intended for cereals, and if just one filled basket weighs some 70 to $80 \mathrm{~kg}$, we can imagine the weight on an ordinary storehouse floor. Cereals were stored directly on the floor, and keeping such staple foods in good condition as long as possible involved a challenge. The solution developed was to raise the whole storehouse, thereby preventing the floor from absorbing the ground's humidity. The problem of humid air could not be removed but it could be mitigated. As the pillars raised the whole structure, the outer surface area increased significantly and the wind aerated the floor as well as the walls.

Figure 12a. Espinaredo, Spain

Figure 12b. Bosco Gurin, Switzerland

Figure 12c. Stübing, Austria

Figure 12d. Bygdoy, Norway

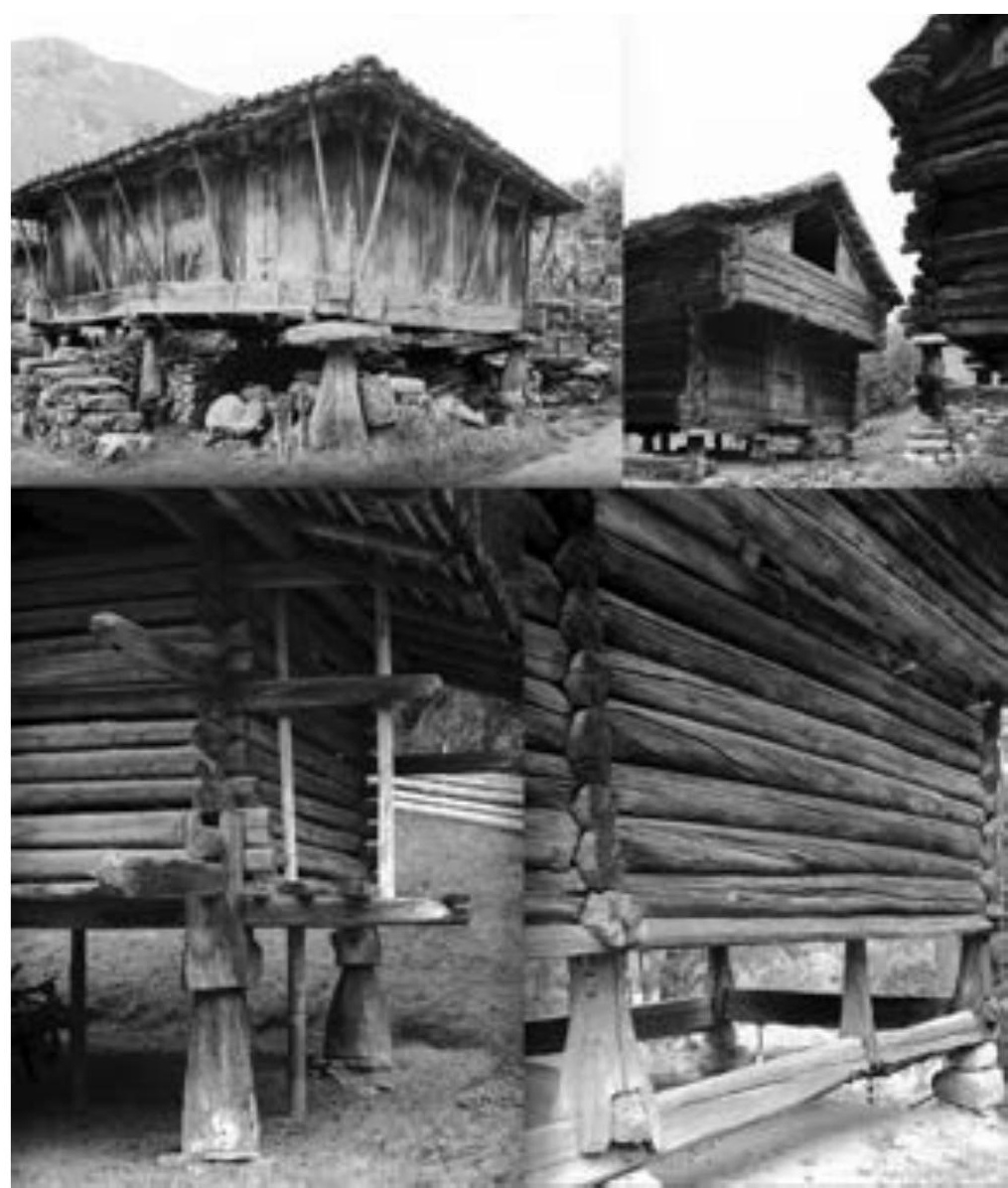


Figure 13a. Wood church in Bogdan Voda, Romania Figure 13b. The 5-storied pagoda at Haguro san

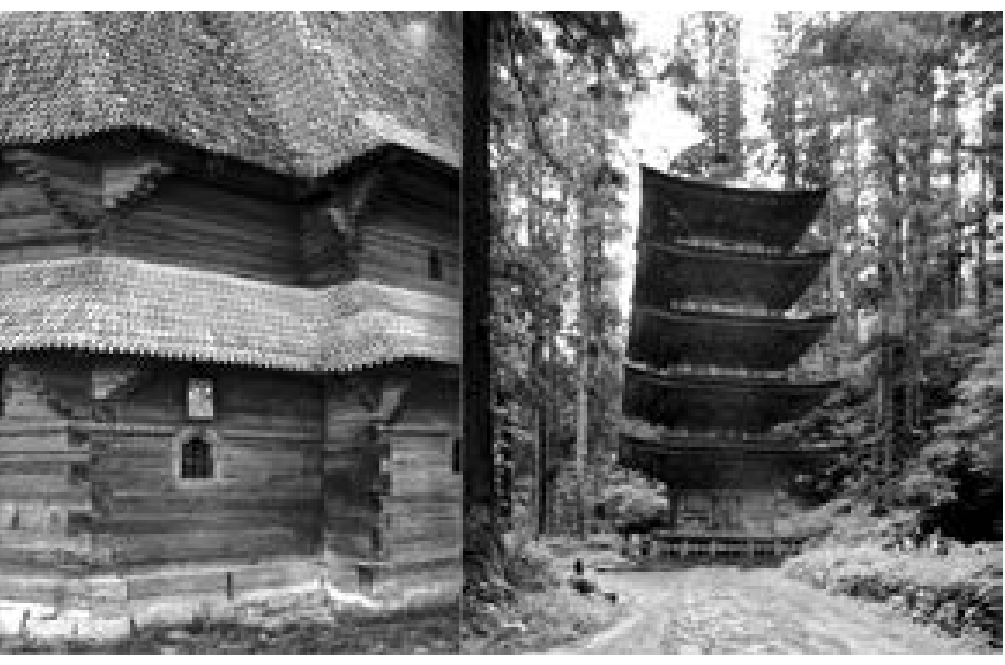

Figure 14a. Gable side of a store house in Aki shi

Figure 14b. Gable-sided facade of a dwelling house in Trogen, Switzerland

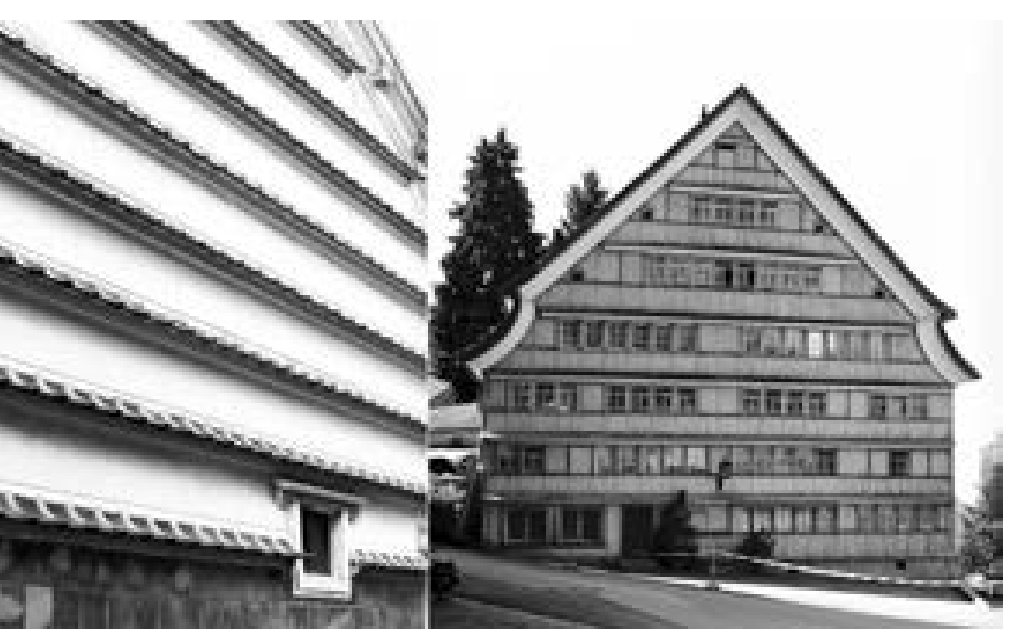

Figure 15a. Detail of a corner of Tōshōdai-ji hozo in Nara

Figure 15b: This log building in Kruszyniany, Poland, is built of halved logs. The advantage of flat inside walls cannot offset the building's poor execution

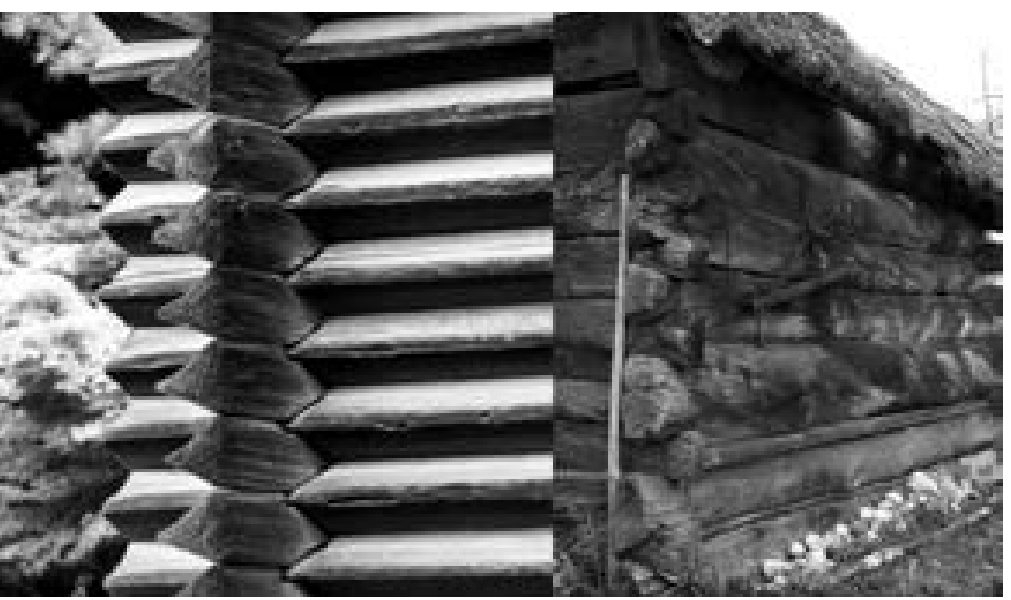

We also find similarities in the way buildings are roofed (Fig. 13). The best protection for wood against the rain and sun is, as for humans, an umbrella or parasol. The better we are covered, the more protected we feel, for a small umbrella keeps only our head dry. But if it is too large it will be heavy and blown about, and tall people with umbrellas tend to get wet anyway. We can change our clothes, but buildings deteriorate if they are constantly exposed to the elements. So carpenters build structures with sufficient roofing to protect both head and body.

Consider townhouses (Fig. 14). As they normally stand close to one another, they require specific solutions. In Aki shi, a town on the south coast of Shikoku, torrential rain during typhoons forced the inhabitants to develop serial rain gutters, one above the other. Their houses' structural skeletons were walled and covered with earth, as a mere additional coat of plaster was deemed insufficient to protect the earth from rainwater. Trogen, a town in Switzerland, appears to have suffered from heavy rain as well. Here the houses were also skeleton structures, covered on the outside with decorative wooden paneling. The paneling was intended to shield the house structure itself, as attached pent roofs protruding far enough to be effective would deprive the windows of light. Comparable to the Japanese solution, a form of construction was developed with slightly protruding rain gutters above each row of windows in order to drain off at least some of the rain via drip moldings above each row.

Our next example is exceptional for its inconspicuousness. I return to a detail of the wall of a Japanese temple storehouse (Fig. 15). At first sight the beams seem to be cut triangularly, but in fact the edges are chamfered. Having beam above beam in a log structure with the contact area reduced to a line gives one an uneasy feeling, and the invisible joints are rather complex. But this does not disqualify this kind of building. Japanese carpenters seem to have taken pleasure in challenging tasks. The bemused question of a Western scholar concerns the idea behind it: what sense can there be in stacking logs in such an unstable way? One answer taking account of wood's properties would be that triangular sections were split out of logs and so this arrangement would prevent any drying of cracks and use the material in the most efficient way. Careful examination does not support this theory. Only dendrochronological verification would allow us to tell if the logs in the photo are originals or replacements. If the logs are original, our split$\log$ theory would be disproven. If the logs are from repairs or reconstructions, we can say nothing about what the original logs looked like. But this example can be compared to the kind of log wall to be found in an area of Poland that evidently experienced a wood shortage. It is no accident that all the beams are extremely short and with spiral growth, but we do not know if this is linked to the erection of walls of halved timbers. Again we find logs stacked edge to edge. In both the Japanese and the Polish examples there is a flat surface inside. The Japanese example is today visible 
Figure 16. This painting shows a Japanese storehouse from 12th century (Seckel 1959: 109)

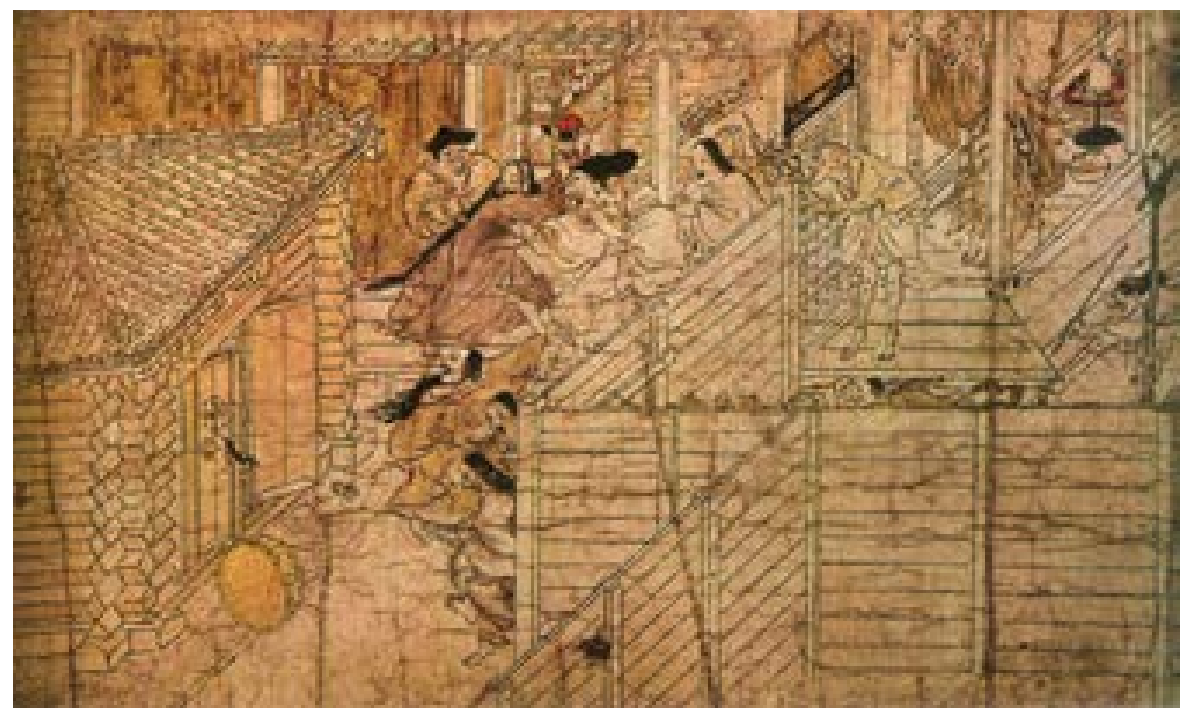

only in temple or shrine compounds, whereas the Polish example has no pretension to being a treasure chamber. We do not know whether the Japanese detail was also used for ordinary storehouses in former times. But a reference here could be the storehouse depicted in a Shigi san engi picture scroll from the late 12th century (Fig. 16). In this scroll a storehouse features in a story about a rich man and the monk Myōren. In the storehouse shown, all the logs have a square section, but they are not stacked one flat surface on another. As in the temple storehouses, they are assembled edge on edge.

A recently completed research program that gave rise to this paper gives us a last example (Zwerger 2020). Wherever it was impossible to dry ripe grain directly in the fields, drying racks had to be erected (Fig. 17). This could be for reasons of climate, topography, grain type, and so on. Just by looking at pictures, it is not so easy to tell which rack is Japanese and which European (Fig. 18). Japanese farmers were able to create these drying devices independently, and temporarily. European farmers had the same idea. The sometimes huge yet simple racks could and did become actual architectural buildings under certain circumstances (Fig. 19). The most elaborate examples combine a dwelling house, a storehouse, or a stable with drying racks around it (Fig. 20). These mature structures could not be built by farmers themselves, as their erection required the knowhow of professional carpenters. Sometimes, even without erecting temporary drying racks, farmers used similar makeshift solutions for drying (Fig. 21).

Figure 17. Single drying racks need braces against the wind, and these have to be installed in a way that does not make the rack difficult to handle (Abfaltersbach, Austria)

Figure 18. The extremely steep slopes in the Takikawa-mura area allow bracing on only the upper side

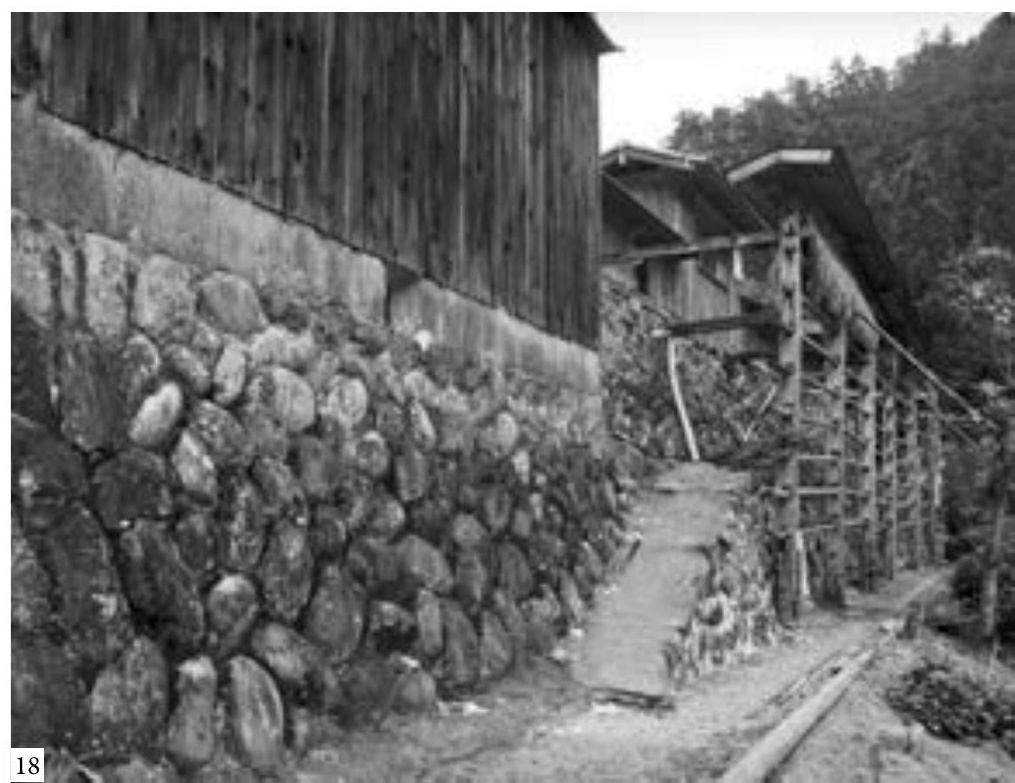



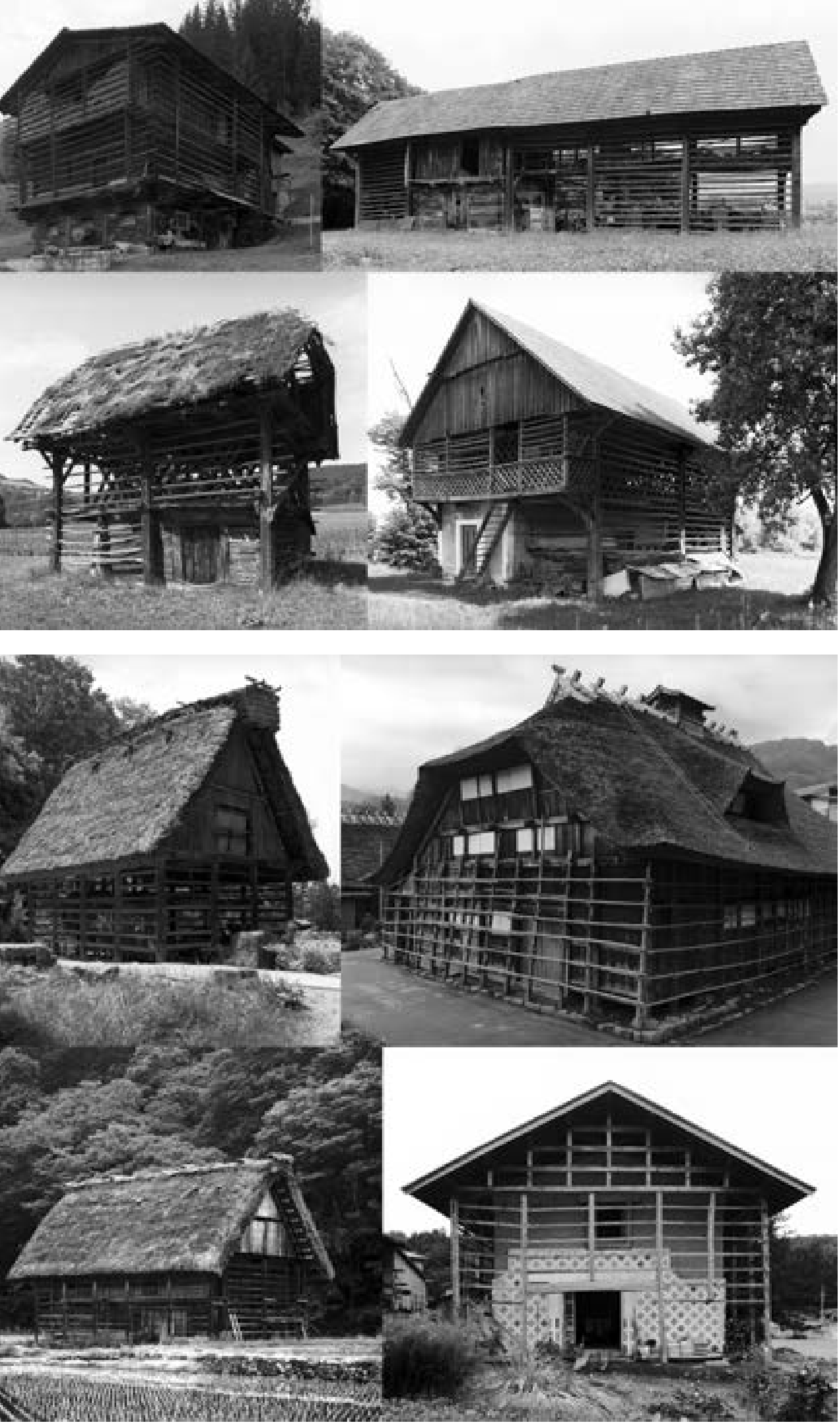

Figure 19a. Drying ladders can be hung around house walls (Mattling, Austria)

Figure 19b. They can also be attached to a storehouse as structurally connected double racks, with all elements thus combined under one roof (Prelaško, Slovenia)

Figure 19c. Double drying racks under a carpenter-made roof can stand over a storehouse (Podsreda, Slovenia)

Figure 19d. They can also be attached to a farmhouse, creating a combined dwelling, stable, storehouse, and drying rack (Dobrava, Slovenia)
Figure 20a. This double cereal drying rack with storage space under the roof makes use of the open gable for extra hanging capacity (Shirakawa-mura) Figure 20b. At harvest time, farmers erect drying racks temporarily round their houses, making use of the warmth reflected by the walls (Tamugimata)

Figure 20c. By contrast with the previous example, these drying racks do not support the roof. And unlike the example from Tamugimata, these racks are structurally integrated in the storehouse (Ogi-machi)

Figure 20d. This drying rack surrounds a fire-protected storehouse in Miyamorimura. The rack supports the overhanging gable and eaves while the roof's main weight rests on the storehouse 
Figure 21a. These makeshift structures are erected in hours. They need scarcely any maintenance. They consume no material apart from rope. Once dismantled, the place is left as it was before. Economy and ecology at their best! (Sanpoku machi-Ogoto)

Figure 21b. Takayanagi machi Figure 21c. Takayanagi machiTochigahara

Figure 21d. Nakanokuchi mura

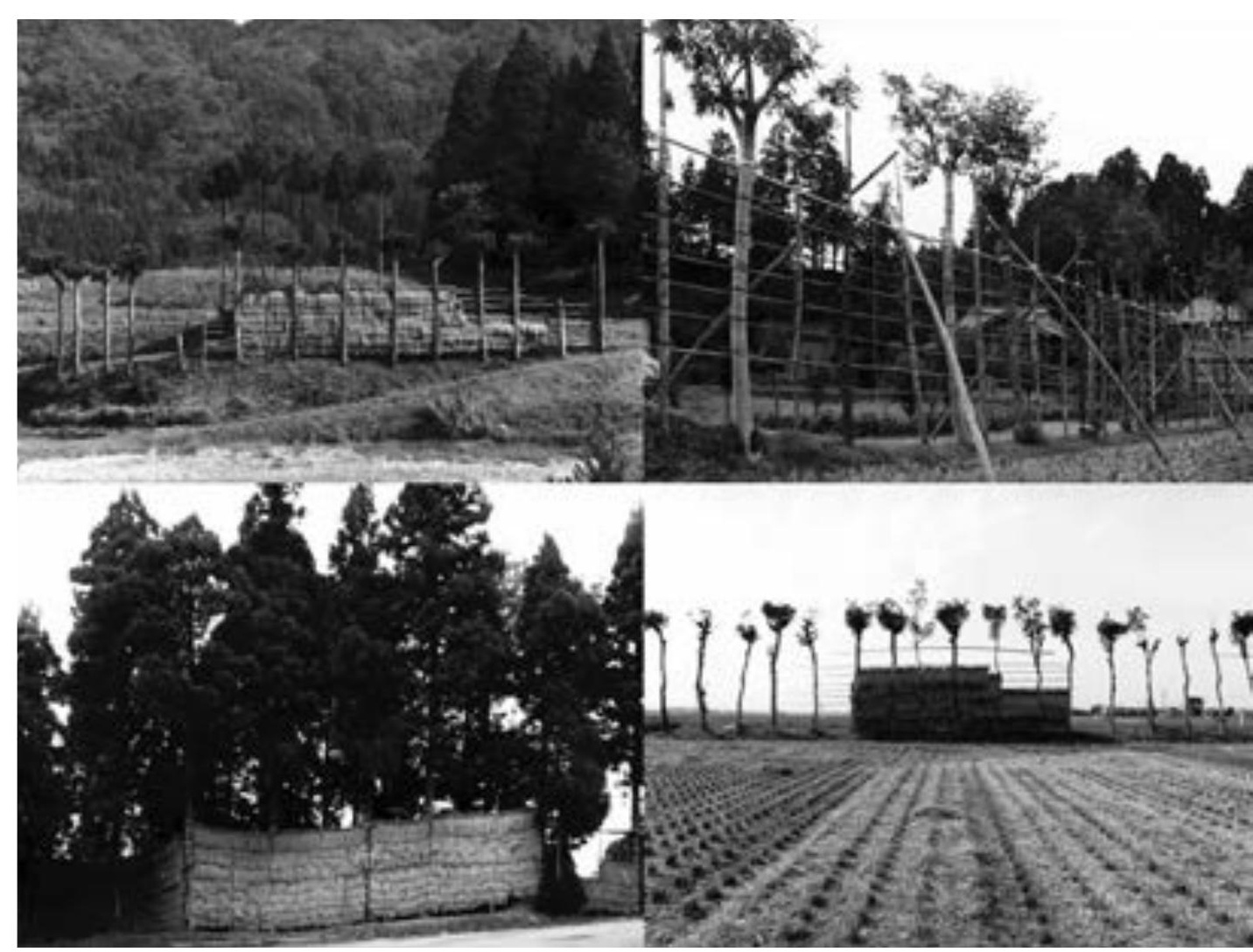

\section{Conclusion}

If the examples presented here were mixed up, it would be challenging for many to guess correctly which building is European and which Japanese. All the structural details are similar at first sight, though naturally close inspection reveals significant differences of composition.

The reason for putting Japanese and European examples side by side is to show strikingly similar solutions expressing identical ways of thinking. This is especially observable in elements which are less subject to cultural influence.

I leave all explanations of how and why aside, and just conjecture about a shared logical reasoning.

I would like to return to my introductory considerations. Friendship requires appreciation, acceptance of the "other", no matter whether the "other" is created artificially, constructed by erroneous assumptions, or has real differences.

In connection with the Japanese and European storehouses we mentioned above or the storehouses clad with drying racks, we might have spoken of $m a$, the Japanese term for "the space in between" (Snodgrass 2004; Vergese 2003), using it to emphasize that visually equal appearances must not be mistaken for equal realities. Nonexistent terms do not demonstrate the inexistence of what they refer to; what they show is that awareness of perception can develop in very different ways.

The "other" remains strange as long as it is insufficiently known. What is needed is to support scientific exploration of all phenomena that serve a growing together; a confluence respecting different approaches based on different cultural educations but which initially and ultimately respond to the same basic realities. Walter Gropius was another voice among the purely personal interpreters of Japanese architectural peculiarities (Gropius 1967: 83, 100). I doubt he would repeat some of his words today, yet I subscribe to one of his statements without hesitating: "The physical world has become too small to allow ourselves to go on living in parallel ignorance of each other" (Ibid., 82).

I propose that it may be interesting to develop the investigation of architectural expression emphasizing similarity and likeness and not just focusing on "otherness". Yet we must not err as in the examples we criticized and present pure visual impressions of similarity as actual equality. The contrasted European and Japanese artefacts raise the question of to what extent they are equal.

On launching such an investigation we will also have to reconsider "our" artifacts. The reason is given in the headline of an interview with Gion Caminada: "To feel our own differently in a new context" (Schoper 2017: 17). 
However, this investigation should not be confined to architecture. For as Adolf Muschg says: "Each culture captures the construction of perception underlying its world in its language. Entirely different worlds are the result of a comparison, even though they might match seemingly on their surface" (Muschg 2007: 211).

${ }^{1}$ The first world exhibitions presenting Japan, as a participant, to a world audience were held in London in 1862, in Paris in 1867, and in Vienna in 1873. For Vienna, see Zwerger, 2007-08.

${ }^{2}$ Oscar Wilde made a mocking yet refreshing comment in 1891: "Do you really imagine that the Japanese people, as they are presented to us in art, have any existence? If you do, you have never understood Japanese art at all. The Japanese people are the deliberate self-conscious creation of certain individual artists. [...] In fact the whole of Japan is a pure invention. There is no such country, there are no such people." (Wilde 2019: 24-25)

${ }^{3}$ The range of discussion on this topic is great.
4 "We ought to imitate bees, if I can put it that way: wandering about, sampling the flowers, they arrange whatever they've gathered, distributing it among the honeycomb's cells, and by blending in the peculiar quality of their own spirit they transform the diverse kinds of nectar into a single taste." (Macrobius 2011, Conviviorum primi diei Saturnaliorum/The festivities of the first day of the Saturnalia, sentence 5)

${ }^{5}$ During a skirmish between the Miyoshi and Matsunaga clans, most buildings in the temple complex were burned down in 1567 .

${ }^{6}$ Photographs showing the technical inner life were taken during repair work; see Nara Bunkazai Hozon Jimusho 1967, figs. 164-166.

${ }^{7}$ The interdependence of climate and culture is wonderfully described by Tetsuro Watsuji.

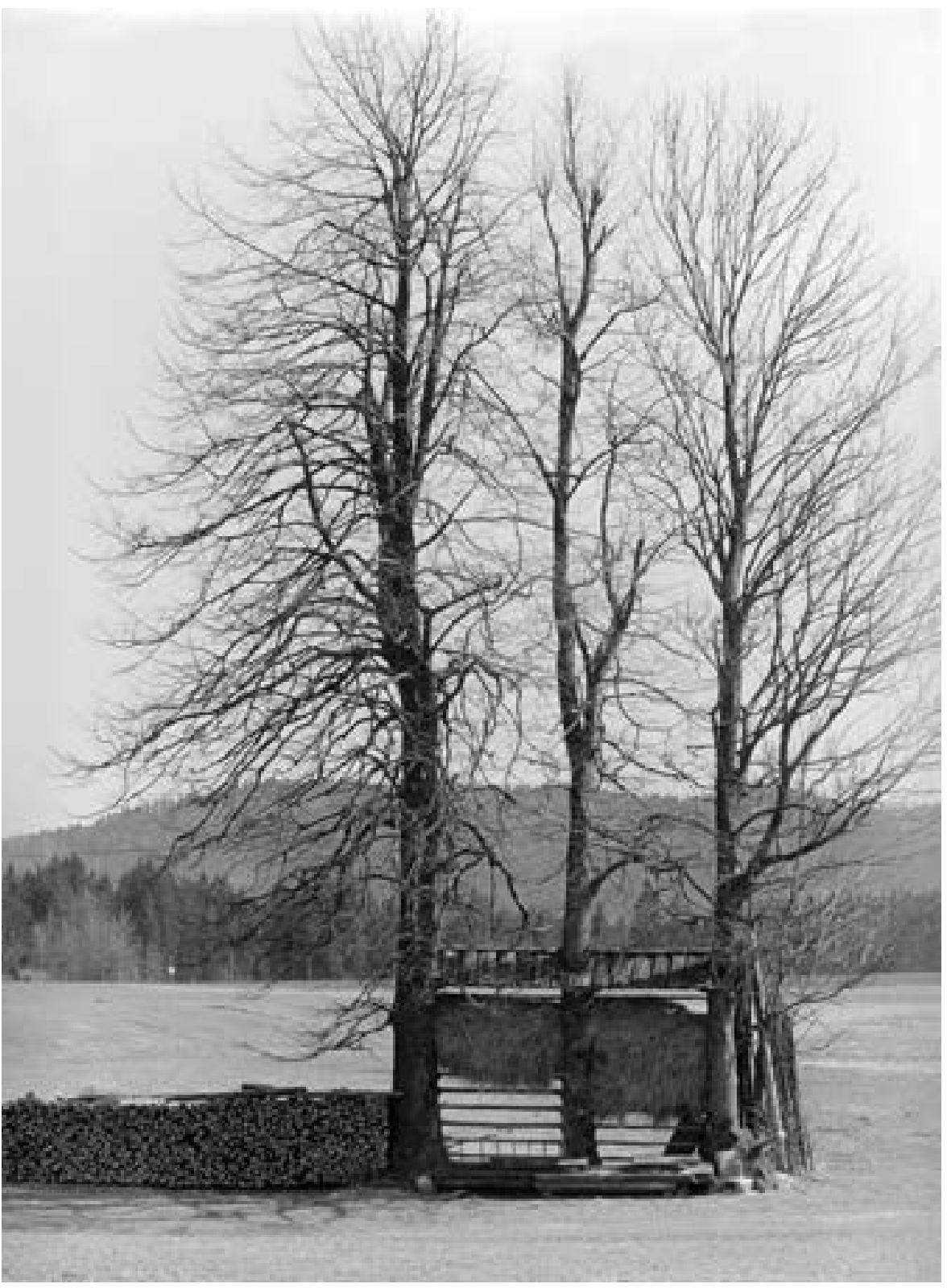




\section{References $\mid$ Referencias $\mid$ Referências}

Ando, Ryosuke. 1991. Nara rokudaiji daikan; Horyuji I. Tokyo.

Barthes, Roland. 1983. The Empire of Signs. Translated by Richard Howard. New York: Hill and Wang.

Bognar, Botond. 1988a. Archaeology of a Fragmented Landscape. In Papadakis, Andreas (ed.), Japanese Architecture, 15-25. London: Academy Editions.

Bognar, Botond. 1988b. The Japanese Order of Things: Notes on Humanism and the Man-Environment Relationship in Japan. In Form, Being, Absence: Architecture and Philosophy, 2, 148-162. New York: Rizzoli International.

Ciorra, Pippo; and Ostende, Florence. 2016. Japaneseness. The Japanese House: Architecture and Life after 1945, 67-83. Venice: Marcilio Editori.

Edlinger, Astrid. 2008. The Japanese Example - or the Art of Appropriation. In Herrle, Peter et al. (eds.), Architecture and Identity, 57-71. Berlin: Lit.

Engel, Heinrich. 1964. The Japanese House: Tradition for Contemporary Architecture. Rutland: Tuttle.

Gropius, Walter. 1967. Apollo in der Demokratie. Mainz: Kupferberg.

Herrle, Peter. 2008. Architecture and Identity? Steppenwolf and the Carriers of Change. In Herrle, Peter et al (eds.), Architecture and Identity, 11-22. Berlin: Lit.

Isozaki, Arata. 2011. Japan-ness in Architecture. Cambridge: MIT Press.

Löffler, Beate. 2015a. The Perpetual Other. Western Architecture in the Western Imagination. International Journal for History, Culture and Modernity, vol. 3, 3: 82-112.

Löffler, Beate. 2015b. Beständiger Wandel. Japanische Architektur als interpretatorische Verfügungsmasse (1850-2015). In Picht, Laura et al. (eds.), The Limits of Change. Was ist der Wert der beständigen Dinge?, 197-213. Berlin: Neofelis Verlag.

Macrobius, Ambrosius Theodosius. [431] 2011. Saturnalia. Edited and translated by Kaster, Robert A. Cambridge: Harvard University Press.

Mitsutani, Takumi. 2003. A Dendrochronological Investigation of Construction Materials Used in the Shosoin Repository. Bulletin of Office of the Shosoin Treasure House, vol. 25: 81-84. https://shosoin kunaicho.go.jp/en-US/bulletin?p=3 (consulted on 16/02/2021).

Mitsutani, Takumi. 2006. A Dendrochronological Investigation of Construction Materials Used in the Shosoin Repository. Bulletin of Office of the Shosoin Treasure House, vol. 28: 66-70. https://shosoin. kunaicho.go.jp/en-US/bulletin?p=3 (consulted on 16/02/2021).

Mitsutani, Takumi. 2016. A Dendrochronological Investigation of Construction Materials Used in the Shosoin Repository (III). Bulletin of Office of the Shosoin Treasure House, vol. 38: 81-88. https://shosoin. kunaicho.go.jp/en-US/bulletin?p=2 (consulted on 16/02/2021).

Muschg, Adolf. 2007. Wegbeschreibung minimal. In Wolfsberg, Kunstmuseum (ed.), Japan und der Westen. Die erfüllte Leere, 211-219. Köln: DuMont.

Nara Bunkazai Hozon Jimusho (Ed.). 1967. Kokuhō Tōdaiji Shōrō Shūri Kōji Hōkokusho. Nara: Nara Bunkazai Hozon Jimusho.

Nish, Ian. 1998. The Iwakura Mission in America and Europe. A New Assessment. Richmond: Japan Library.

Nitschke, Günter. 2002. Architektur und Ästhetik eines Inselvolkes. In Schittich, Christian (ed.), Im Detail: Japan. Architekten, Konstruktionen, Stimmungen, 15-35. Basel: Birkhäuser.

Pantzer, Peter. 2002. Kume Kunitake: Die Iwakura-Mission. Das Logbuch des Kume Kunitake über den Besuch der japanischen Sondergesellschaft in Deutschland, Österreich und der Schweiz im Jahre 1873. München: Ludicium Verlag.
Schiermeier, Kris. 2014. Imitation oder Innovation? Van Goghs Japonaiserien und die japanische Kunst der Meiji-Zeit. In Irvine, Gregory (ed.), Der Japonismus und die Geburt der Moderne. Die Kunst der Meiji-Zeit, 140-165. Leipzig: Seemann.

Schoper, Tom. 2017. Ähnlichkeit und Differenz. In neuem Kontext das eigene anders spüren. In Ein Haus. Werk - Ding - Zeug?, 17-49. Wien: Passagen Verlag

Seckel, Dietrich. 1959. Emakimono. Translated by Maxwell Brownjohn. London: Jonathan Cape.

Snodgrass, Adrian. 2004. Thinking through the gap: The space of Japanese Architecture. Architectural Theory Review, vol. 9, 2, 65-85.

Speidel, Manfred (ed.). 2003. Bruno Taut. Ich liebe die japanische Kultur. Kleine Schriften über Japan. Berlin: Gebrüder Mann.

Speidel, Manfred. 2009. Nachwort. In Taut, Bruno. Nippon mit europäischen Augen gesehen. Berlin: Mann.

Taut, Bruno. 1936. Grundlinien der Architektur Japans. Tokyo: Kokusai Bunka Shinkokai.

Taut, Bruno. 1937. Houses and People of Japan. Tokyo: Sanseido.

Tetsurō, Watsuji. 2017. Fūdo; Wind und Erde: Der Zusammenhang zwischen Klima und Kultur. Berlin: Matthes \& Seitz.

Verghese, George. 2003. The Way of the Detail in Japanese Design. IDEA Journal, vol. 4, 1: 161-172.

Wilde, Oscar. [1891] 2019. Intentions. GlobalGrey. https://www. globalgreyebooks.com/intentions-ebook.html (consulted on 14/02/2021)

Yoshioka, Hiroshi. 1995. Samurai and self-colonization in Japan. In Pieterse, Jan N. (ed.), The decolonization of imagination, 99-112. London: Zed Books.

Zwerger, Klaus. 2007-08. Präsentation japanischer Baukultur im Wien des 19. Jahrhunderts. Archiv, 57/58: 18-220.

Zwerger, Klaus. 2020. Cereal Drying Racks: History and Typology of Wood Buildings in Europe and East Asia. Basel: Birkhäuser.

\section{Biography | Biografía | Biografia}

\section{Klaus Zwerger}

Klaus is an Associate Professor at the Institute of Architecture and Design at the University of Technology in Vienna (TU Wien), Austria. He has been granted three long-term scholarships to work as a guest researcher at Todai (University of Tokyo). He has been invited as a guest professor to Hosei University in Tokyo, held several lecture series, and run numerous seminars and workshops at various universities in China and Europe. As of autumn 2021 he is professor at SEU in Nanjing. Working as a joiner and carpenter, he collected experience with wood. His scientific research is focused on historic timber architecture. He specializes in comparative East Asian and European building traditions and has published widely on this topic. His most recent monograph was published in 2020. 